\title{
BPIFA1 wt Allele
}

National Cancer Institute

\section{Source}

National Cancer Institute. BPIFA1 wt Allele. NCI Thesaurus. Code C118517.

Human BPIFA1 wild-type allele is located in the vicinity of 20q11.21 and is approximately

$7 \mathrm{~kb}$ in length. This allele, which encodes BPI fold-containing family A member 1 protein,

may play a role in anti-bacterial defense in the upper airway. This gene may be associated with micrometastasis in non-small-cell lung carcinoma. 